\title{
PENGARUH MODIFIKASI TIGA VARIETAS TEPUNG UBI JALAR DAN TERIGU TERHADAP KUALITAS DAN DAYA TERIMA MI KERING
}

\author{
Ni Wayan Sukerti,Damiati, Cok. Istri Raka Marsiti, NDMS.Adnyawati \\ Jurusan Pendidikan Kesejahteraan Keluarga, Fakultas Teknik dan Kejuruan \\ Universitas Pendidikan Ganesha, \\ Singaraja, Indonesia \\ e-mail : Sukertiyan@yahoo.com
}

\begin{abstract}
Abstrak
Penelitian ini bertujuan untuk mengetahui : (1) Pengaruh modifikasi tepung ubi jalar putih dan terigu terhadap kualitas dan daya terima mi kering ; (2) Pengaruh modifikasi tepung ubi jalar orange dan terigu terhadap kualitas dan daya terima mi kering; (3) Pengaruh modifikasi tepung ubi jalar ungu dan terigu terhadap kualitas dan daya terima mi kering.

Jenis penelitian ini adalah penelitian eksperimen. Desain penelitian eksperimen ini menggunakan factorial ganda $3 \times 3$ yaitu pengaruh modifikasi tiga varietas tepung ubi jalar terhadap kualitas dan daya terima mi kering. Sedangkan teknik pengumpulan data dilakukan melalui uji mutu organoleptik dengan parameter yaitu aroma, rasa, tekstur,. Panelis yang dilibatkan sebanyak 40 orang, yang terdiri dari panelis terlatih (6 orang) dan panelis semi terlatih 34 orang. Selanjutnya data yang terkumpul dianalisis secara deskriptif, dan analisis Varian Klasifikasi Ganda (ANAVA GANDA) dengan program SPSS for windows Versi 16 dan uji t.

Hasil penelitian menunjukkan (1) bahwa terdapat pengaruh yang signifikan modifikasi tepung ubi jalar putih dengan terigu terhadap kualitas aroma mie kering dengan (mean) sebesar 2,52 pada kategori baik. Sedangkan daya terima responden berada pada kategori cukup disukai; (2) Terdapat pengaruh yang signifikan modifikasi tepung ubi jalar orange dengan terigu terhadap kualitas aroma dengan (mean) sebesar 2,52 pada kategori baik, sedangkan aspek rasa mie kering dengan (mean) sebesar 2,58 pada kategori baik. Sedangkan daya terima responden pada kategori disukai ; (3) Terdapat pengaruh yang signifikan modifikasi tepung ubi jalar ungu dengan terigu terhadap kualitas aroma mie kering dengan (mean) sebesar 2,82 pada kategori baik. Sedangkan daya terima responden pada kategori cukup disukai.
\end{abstract}

Kata Kunci: Modifikasi Tepung Ubi Jalar ,Mi Kering

\section{Abstract}

The main concern of this study is to find out: (1) Is there any effect of the modification of white sweet potato and wheat flour toward the quality and acceptance of dry noodle? (2) Is there any effect of orange sweet potato and wheat flour modification toward the quality and acceptance of dry noodle? (3) Is there any effect of purple sweet potato and wheat flour modification toward dry noodle quality and acceptance?

This research was conducted as an experimental study. Design of this experiment study used multiple factorials $3 \times 3$ that showed the effect of three varieties modification of sweet potato and wheat flour varieties modification toward the quality and acceptance of dry noodle. While, in collecting data, this research was conducted through the organoleptik quality test that used parametric, such as: fragrance, taste, and form. There were 40 panelists who participated, consisted of: 6 trained panelists and 34 semi-trained panelists. Then, the data that had been collected were analyzed descriptively, and used Multiple ANAVA by using SPSS program for 16 version windows and T-test.

The findings of this study showed that: (1) there was significant effect of white sweet potato and wheat flour modification toward the quality of dry noodle fragrance by the result of their mean are 2,52 in good category. However, for the acceptance of respondents 
to the white sweet potato dry noodle, it showed in average category with mean 2,$3 ;(2)$. There was significant effect of orange sweet potato and wheat flour modification to the fragrance of dry noodle quality by the result of their mean 2,52 in good category, however, for the aspect of the dry noodle taste, it had mean 2,58 which was in good category and respondents acceptance to the orange sweet potato and dry noodle in preferable category with mean 3.0 ; (3) There was significant effect of purple sweet potato and wheat flour modification to dry noodle fragrance quality by the result of their mean 2,82 in good category, for respondents acceptance to the purple sweet potato and dry noodle in average category with mean 2.0 .

Key Words: Modification, Flour, Sweet Potato, Dry Noodle

\section{PENDAHULUAN}

Ubi jalar (Ipomea batatas L) merupakan sumber karbohidrat dan sumber kalori (energi) yang cukup tinggi, dan menduduki peringkat keempat setelah padi,jagung, dan ubi kayu. Produk ubi jalar tidak hanya potensial sebagai sumber karbohidrat dalam tatanan bahan pangan bagi sebagian penduduk dunia, tetapi juga multiguna sebagai bahan baku berbagai industri pengolahan pangan.Untuk menghindari terjadinya kerusakan atau penurunan kualitas selama penyimpanan pada ubi jalar maka perlu dilakukan penanganan lebih lanjut yaitu pengolahan dalam bentuk segar maupun tepungnya. Hal ini, untuk mengurangi jumlah ubi jalar yang terbuang percuma karena rusak ataupun busuk pada saat penyimpanan selama panen raya, meningkatkan daya guna ubi jalar, meningkatkan daya simpan.

Selain itu pemanfaatan ubi jalar menjadi produk awetan (tepung) bertujuan mempertahankan mutu dan kualitas produk. Pemanfaatan tepung ubi jalar yang merupakan produk setengah jadi sebagai bahan substitusi terigu untuk bahan baku industri pengolahan makanan tentunya akan meningkatkan peranan komoditas ubi jalar dan system ketahanan pangan nasional.

Tepung ubi jalar dapat digunakan sebagai bahan substitusi tepung terigu, karena dapat digunakan sebagai bahan baku pembuatan produk roti (bakery) dan mi. Secara garis besar pembuatan tepung adalah pengupasan, pengirisan atau penyawutan mengguakan alat atau manual, pencucian, penjemuran atau pengeringan menggunakan oven pada suhu 500C selama 40 jam hingga kandungan air sekitar $7 \%$, kemudian penggilingan atau penepungan dan pengayakan 80 mesh (Suprapti,2003)

Pada pembuatan mi campuran tepung ubi jalar berkisar 20\%.-30\%. Mi tersebut mengandung $11 \%$ air; $11 \%$ protein; 0,9\% lemak; $76 \%$ karbohidrat dan $1 \%$ abu (Antarlina dan Utomo, 1997). Cara pembuatan mi secara garis besar adalah pembuatan adonan yang merupakan campuran $20 \%$ tepung ubijalar, $80 \%$ terigu, telur, garam, dan air. Kemudian pembentukan lembaran (diulang 6 kali), pemotongan/pencetakan mie, peminyakan, perebusan hingga dihasilkan mie kering. Salah satu produk pangan yang akan diolah dengan memanfaatkan substitusi tepung ubi jalar adalah mi kering. Secara umum mi dapat digolongkan menjadi dua, mi kering dan mi basah. Mi basah adalah mi yang dipasarkan dalam keadaan mentah, biasanya jenis mi ini memiliki daya tahan 1 sampai 2 hari. Mi kering adalah mi basah yang melewati tahap penggorengan /penjemuran sehingga memiliki daya tahan yang lebih lama. Pemilihan mi kering atas dasar pemilihan bahan yang mudah diperoleh, mudah pengolahannya, rasa yang legit, aroma khas, praktis serta disukai masyarakat.

Berdasarkan uraian pada latar belakang di atas, maka dapat dirumuskan permasalahannya sebagai berikut: Apakah ada pengaruh modifikasi tepung tiga varietas ubi jalar dan terigu terhadap kualitas dan daya terima produk mi kering? 
Berdasarkan rumusan masalah tersebut, maka tujuan penelitian secara umum adalah; untuk mengetahui pengaruh modifikasi tiga varietas tepung ubi jalar dan terigu terhadap kualitas dan daya terima panelis pada produk mi kering

\section{METODE PENELITIAN}

Penelitian ini dilaksanakan di laboratorium Produksi (Kitchen) Jurusan Pendidikan Kesejahteraan Keluarga. Waktu pelaksanaan penelitian selama 9 bulan mulai bulan Maret 2012 sampai dengan bulan Desember 2012. Jenis Penelitian yang dilakukan adalah penelitian lanjut jenis eksperimen. Desain eksperimen adalah suatu rancangan percobaan dengan tiap langkah yang benar-benar terdefinisikan sedemikian rupa, sehingga informasi yang berhubungan dengan atau diperlakukan untuk permasalahan yang sedang diteliti dapat dikumpulkan.(Leksono Lestarijadi dkk,2008:40). Desain yang digunakan dalam penelitian ini adalah factorial ganda $3 \times 3$ yaitu pengaruh modifikasi tiga varietas tepung ubi jalar dan terigu. Selanjutnya diolah dengan perbandingan tepung terigu $70 \%: 30 \%$.

Subjek penelitian ini adalah tepung ubi jalar (putih, orange,dan ungu) yang dimodifikasikan ke dalam tepung terigu. Sedangkan Objek penelitian ini adalah mi kering hasil pengembangan tepung ubi jalar yang diuji kualitas dan daya terima sesuai dengan parameter aroma, rasa, tekstur, dan tingkat kesukaan panelis. Instrumen Penelitian menggunakan uji kualitas yaitu uji mutu organoleptik meliputi penilaian dari parameter aroma, rasa, tekstur, dan tingkat kesukaan panelis. Uji organoleptik merupakan penilaian yang dilakukan dengan indera manusia. Selain menggunakan uji organoleptik, peneliti juga menggunakan pengujian mutu hedonik, yaitu panelis diminta tanggapan tentang kesan baik dan buruknya produk hasil eksperimen, melalui skala mutu yang terdiri dari 3 tingkatan. Nilai yang diberikan oleh panelis adalah $1=$ kurang , 2 = cukup baik, 3 = baik, (Suwarno,1997)

Sesuai dengan jenis penelitian ini yaitu penelitian eksperimen, maka teknik pengumpulan data dilakukan melalui observasi uji mutu organoleptik dengan parameter yaitu aroma, rasa, tekstur, dan tingkat kesukaan panelis. Panelis yang dilibatkan dalam penelitian ini adalah sebanyak 40 orang panelis, yang terdiri dari panelis terlatih dalam hal ini dosen Tata boga sebanyak 6 orang dan panelis semi terlatih yakni mahasiswa tata boga sebanyak 34 orang. Setiap panelis diberikan lembar observasi yang berisi kreteria penilaian, dimana panelis hanya mencentang pada kolom penilaian sesuai dengan produk yang diamati dan dicicipi. Selanjutnya lembar observasi dikumpulkan, untuk ditabulasi dan dianalisis. Teknik analisis data yang digunakan dalam penelitian ini adalah Analisis deskriptif dan analisis Varian Klasifikasi ganda (ANAVA GANDA) dengan program SPSS for Windows Versi 16 dan Uji t. Analisis deskriptif dilakukan terhadap data yang diperoleh selama uji formatif yaitu uji mutu organoleptik dengan parameter aroma, rasa, tekstur, dan tingkat kesukaan yang dilakukan panelis. Sedangkan analisis varian dan uji $t$ dilakukan terhadap data yang diperoleh dalam uji sumatif untuk menguji apakah ada perbedaan pengaruh modifikasi penggunaan tepung terigu dan tepung ubi jalar dalam pembuatan mi kering terhadap mutu organoleptik dengan paramenter aroma, rasa, tekstur, serta tingkat kesukaan panelis.

\section{HASIL PENELITIAN DAN PEMBAHASAN}

Tabel 4.1 Hasil Analisis Deskriptif Uji Mutu Organoleptik terhadap aroma mi kering sebagai berikut :

\begin{tabular}{|l|l|l|}
\hline $\begin{array}{l}\text { Aspek Penilaian } \\
\text { (aroma) }\end{array}$ & Mean & Kategori \\
\hline Mi A & 2.52 & baik \\
\hline Mi B & 2,52 & baik \\
\hline Mi C & 2,82 & baik \\
\hline
\end{tabular}


Berdasarkan tabel di atas, diperoleh bahwa mi kering formula III (Mi C) memiliki mean tertinggi yaitu 2,82 dengan kategori aroma yang terbaik yaitu aroma khas tepung ubi jalar ungu. Hal ini dimungkinkan oleh penggunaan tepung ubi jalar ungu yang memiliki aroma paling tajam dibandingkan dengan tepung ubi jalar putih maupun tepung ubi jalar orange.

Tabel 4.2 Hasil Analisis Deskriptif Uji Mutu Organoleptik terhadap rasa mi kering sebagai berikut :

\begin{tabular}{|c|c|c|}
\hline $\begin{array}{c}\text { Aspek Penilaian } \\
\text { (Rasa) }\end{array}$ & Mean & Kategori \\
\hline Mi A & 2,45 & cukup \\
\hline Mi B & 2,58 & baik \\
\hline Mi C & 2,05 & cukup \\
\hline
\end{tabular}

Berdasarkan tabel di atas, diperoleh bahwa rasa mi (B) memiliki mean tertinggi yaitu 2,58 dalam kategori baik yaitu rasanya gurih.Hal ini dimungkinkan oleh penggunaan tepung ubi jalar orange $30 \%$, dan kandungan glukosa ubi jalar orange juga kuat, menyebabkan hasil mi kering rasanya sesuai degan kreteria yaitu gurih oleh perpaduan penambahan telur dengan tepung ubi yang mengandung glukosa, sehingga campuran yang diperoleh sesuai dengan standar.

Tabel 4.3 Hasil Analisis Deskriptif Uji Mutu Organoleptik terhadap tekstur mi kering sebagai berikut :

\begin{tabular}{|l|l|l|}
\hline $\begin{array}{l}\text { Aspek Penilaian } \\
\text { (Tekstur) }\end{array}$ & Mean & Kategori \\
\hline Mi A & 2,22 & Cukup \\
\hline Mi B & 2,42 & Cukup \\
\hline Mi C & 2,05 & Cukup \\
\hline
\end{tabular}

Berdasarkan tabel di atas, diperoleh bahwa tekstur pada ketiga formula mi $(A, B, C)$ berada pada kategori cukup . Artinya teksturnya kenyal, tetapi penampakannya mudah putus. Hal ini dimungkinkan oleh hanya penggunaan bahan alami berupa tepung ubi jalar, terigu, dan telur, sehingga tingkat kekenyalan mi belum bisa dipertahankan,sehingga mudah putus. Berbeda halnya dengan mi instan buatan pabrik, yang menggunakan bahan kimia yaitu air ki (air abu) untuk meningkatkan kekenyalan dan kehalusan tekstur, sehingga tekstur mi instan tersebut sangat kenyal dan tidak mudah putus.

Selanjutnya berdasarkan analisis tingkat kesukaan panelis (daya terima) terhadap ketiga produk mi kering, diperoleh rata-rata (mean) sebesar 3,0 pada formula mie B. Hal ini berarti mi yang paling disukai menurut panelis adalah mie B (tepung ubi jalar orange) .

\section{HASIL UJI ANALISIS VARIAN \\ Analisis dilakukan dengan bantuan komputer program SPSS Versi} 13.Berdasarkan analisis varians satu jalur ternyata aspek kualitas aroma yang berpengaruh secara signifikan. Adapun ringkasan analisis varian untuk menguji aroma pada ketiga formula $\mathrm{mi}$ dapat ditampilkan pada tabel berikut :

Tabel 4.4 Tabel Ringkasan analisis varians untuk menguji aroma antara mi $A, B$, dan C

\begin{tabular}{|l|l|l|l|l|l|l|}
\hline $\begin{array}{l}\text { Sumber } \\
\text { Variasi }\end{array}$ & JK & Db & $\begin{array}{l}\text { RJ } \\
\text { K }\end{array}$ & Fh & $\begin{array}{l}\text { Fta } \\
\text { b } \\
5 \%\end{array}$ & $\begin{array}{l}\text { Kep } \\
\text { utu } \\
\text { san }\end{array}$ \\
\hline $\begin{array}{l}\text { JK } \\
\text { antar }\end{array}$ & 2,4 & 3 & 1,2 & $\begin{array}{l}4, \\
42 \\
6\end{array}$ & $\begin{array}{l}3,0 \\
7\end{array}$ & $\begin{array}{l}\text { Sig } \\
\text { nifik } \\
\text { an }\end{array}$ \\
\hline $\begin{array}{l}\text { JK } \\
\text { dalam }\end{array}$ & $\begin{array}{l}31,7 \\
25\end{array}$ & 117 & 0,2 & & & \\
\hline Total & $\begin{array}{l}34,1 \\
25\end{array}$ & 119 & & & & \\
\hline
\end{tabular}

Selanjutnya uji asumsi bahwa Ho diterima jika $F \mathrm{~h}$ < F t. $(40 ; 0,05)$ dan Ho ditolak jika $\mathrm{F} \mathrm{h}>\mathrm{F} \mathrm{t}(40 ; 0,05)$ Berdasarkan hasil analisis Anava dengan bantuan komputer menggunakan program SPSS versi 13 diperoleh $F$ h sebesar 4,426. Jika dibandingkan dengan $F$ tabel maka 4,426 > $3,07(\mathrm{~F}$ t) . Hal ini berarti signifikan. Jadi dapat disimpulkan bahwa terdapat 
perbedaan yang signifikan modifikasi tepung ubi jalar (formula mi B, mi C ) terhadap mutu organoleptik (aroma) mi kering. Berdasarkan uji t scheefee, diperoleh harga $t$ untuk formula mi $\mathrm{C}$ dengan mi $\mathrm{C}$ sebesar 2,557 pada taraf siginifikansi 0,05. Hal ini berarti modifikasi tiga varietas tepung ubi jalar pada formula mi B (tepung ubi jalar orange) dan mi $C$ (tepung ubi jalar ungu) mempengaruhi mutu organoleptik dari aspek aroma. Mutu Organoleptik aroma terbaik terdapat pada formula mi C (tepung ubi jalar ungu) dengan aroma khas dan tajam ubi jalar ungu

Berdasarkan pemaparan hasil penelitian di atas, bahwa formula resep baku mi dengan modifikasi tiga varietas tepung ubi jalar, menurut responden yang telah dianalisis secara statistik menunjukkan ketiga formula (Mi A, B, C) mi kering tepung ubi jalar, menghasilkan mi pada aspek aroma memenuhi kreteria baik, namun aroma terbaik ditemukan pada formula mi $\mathrm{C}$ (tepung ubi jalar ungu). Selanjutnya dari aspek rasa , menurut responden, ditemukan rasa mie yang paling gurih yaitu mie $B$ (tepung ubi jalar orange), sedangkan aspek tekstur pada ketiga formula mi $(A, B, C)$ memiliki tekstur cukup baik, yaitu kenyal tetapi mudah putus. Aspek aroma terbaik ditemukan pada formula mi C (tepung ubi jalar ungu), hal ini dimungkinkan oleh penggunaan tepung ubi jalar ungu, dimana karakteristiknya tepung ubi jalar ungu dari aspek warna cenderung ungu pekat. Selanjutnya berdasarkan analisis Anava,bahwa terdapat perbedaan kualitas (mutu organoleptik) mi kering antara formula mi $B$ dengan formula mi C. Formula mi B menggunakan modifikasi tepung ubi jalar orange, sedangkan formula mi C menggunakan modifikasi tepung ubi jalar ungu. Perbedaannya terjadi pada aspek rasa dan aroma, dimana rasa terbaik ditemukan pada formula mi B, (tepung ubi jalar orange), hal ini dimugkinkan oleh kandungan glukosa ubi orange lebih tinggi dibandingkan ubi lainnya, dan dipadukan dengan bahan tambahan garam dan telur menghasilkan rasa yang gurih. Sedangkan aroma formula mi $\mathrm{C}$ yang terbaik yaitu aroma khas ubi jalar. Hal ini dimungkinkan oleh penggunaan tepung ubi jalar ungu yang memiliki karakteristik aroma paling tajam, yang ditimbulkan oleh warna ungu pekat, walau telah mengalami berbagai proses dari penanganan awal, pengeringan, penggilingan, namun warna tepung ubi jalar ungu tetap pekat. Hal ini sesuai dengan hasil penelitian terdahulu, bahwa tepung dari jenis umbi-umbian dapat menggantikan terigu mencapai $70 \%$ pada aplikasi jenis mi terutama pada aspek rasa dan aroma. Pada sisi lain masih terdapat kelemahan yaitu tekstur mi mudah putus walapun sudah memiliki kekenyalan. Hal ini menurut peneliti disebabkan penggunaan bahan alami tanpa penggunaan bahan kimia (air ki). Namun menurut responden, kondisi itu harus ditingkatkan dengan mengusahakan menggunakan bahan tambahan pengikat tekstur supaya tidak mudah putus, sebab penampilan mie yang kenyal dan tidak mudah putus akan lebih laku dipasaran dibandingkan dengan mie yang alami, dan penampilannya kurang menarik.

Melalui pemanfaatan ubi jalar yang diolah menjadi tepung, ternyata dapat menggantikan terigu dalam pembuatan $\mathrm{mi}$ kering walaupun prosentasenya kecil. Tepung ubi jalar memiliki komposisi maupun kandungan zat gizi yang menyerupai terigu jenis lunak (soft) terutama kandungan pati yang tinggi, dengan kadar gluten yang rendah, yang mana karakteristik tersebut cocok sebagai bahan pembuatan mi khususnya mi kering. Jika tepung ubi jalar dan terigu protein tinggi dicampur, menghasilkan sejumlah protein, yang mampu menyerap cairan sehingga terbentuk gluten. Gluten mempunyai sifat kuat, kenyal dan mampu menahan udara sampai titik maksimum. Sedangkan penambahan telur dan air ki dalam pembuatan mi berguna agar mie bertekstur kenyal dan berasa gurih, serta menambah nilai gizi mi. Pemilihan mi kering didasari atas kemudahan dalam pengolahan, tidak memerlukan peralatan 
yang besar, cukup dalam skala rumah tangga. Hasil penelitian ini selanjutnya dapat disosialisasikan kepada masyarakat melalui Program Pengabdian pada Masyarakat (P2M) khususnya pada masyarakat penghasil ubi jalar. Selain itu hal ini sebagai upaya meningkatkan nilai ekonomi ubi jalar dan terbukanya peluang usaha (home Industry) pembuatan aneka mi kering berbahan tepung ubi jalar.

Penerapan teknologi pengolahan baik sederhana maupun modern dapat meningkatkan citra sumber pangan lokal. Selama ini ubi jalar sering disebut sebagai bahan alternatif pengganti beras (sebagai sumber karbohidrat/kalori) sehingga mengandung pengertian kelas dua. Padahal dengan sentuhan teknologi yang memadai bahan-bahan tersebut dapat digunakan sebagai bahan pengganti nasi seperti makanan kudapan (snack food) baik tradisional maupun dengan teknologi modern (Indrasari, 2000).

\section{SIMPULAN}

Berdasarkan pemaparan pada hasil penelitian dan pembahasan di atas, maka dapat disimpulkan sebagai berikut:

1. Terdapat pengaruh yang signifikan modifikasi tepung ubi jalar putih dengan terigu terhadap kualitas aroma mi kering dengan rata-rata (mean) sebesar 2,52 pada kategori baik. Sedangkan daya terima responden terhadap mi kering tepung ubi jalar putih berada pada kategori cukup disukai yaitu ratarata sebesar 2,3

2. Terdapat pengaruh yang signifikan modifikasi tepung ubi jalar orange dengan terigu terhadap kualitas aroma dengan mean sebesar 2,52 pada kategori baik, sedangkan rasa mi kering dengan rata-rata (mean) sebesar 2,58 pada kategori baik. Sedangkan daya terima responden terhadap mi kering tepung ubi jalar orange berada pada kategori disukai yaitu rata-rata sebesar 3,0
3. Terdapat pengaruh yang signifikan modifikasi tepung ubi jalar ungu dengan terigu terhadap kualitas aroma mi kering dengan rata-rata (mean) sebesar 2,82 pada kategori baik. Sedangkan daya terima responden terhadap $\mathrm{mi}$ kering tepung ubi jalar ungu berada pada kategori cukup disukai yaitu ratarata sebesar 2,0

\section{SARAN}

Berdasarkan hasil penelitian yang telah dipaparkan di depan, maka dapat diajukan saran yaitu bahwa dalam pembuatan mi berbahan tepung ubi jalar masih terdapat kelemahan dari aspek tekstur yang kurang kenyal, sehingga perlu diusahakan mengatasi hal tersebut dengan menambahkan air ki ke dalam adonan.

\section{DAFTAR PUSTAKA}

Arikunto,Suharsimi. 1998. Prosedur Penelitian. Jakarta: Rineka Cipta.

Antarlina. 1998. Tetap Lezat dengan Tepung Ubi Jalar.Balitbangtan. Malang

Badan Penelitian dan Pengembangan Pertanian . 2006.Sallosa dan Pattipi, varietas ubi jalar terbaru inovasi balitbang pertanian. Jurnal Penelitian dan Pengembangan Pertanian.

http://westpapuapoint wordpress.com ubi jalar petatas dan kastela. Makanan khas Papua. Diakses pada tanggal 29 Maret 2009.

Leksono Lestarijadi dkk. 2008. Pengaruh Substitusi Tepung Suweg dan Jumlah Lemak terhadap tingkat Kesukaan Biskuit Berlemak. Artikel pada Prosiding Seminar Nasional "Cara Cerdas Menjadi Kaya Melalui Wirausaha Kuliner" Fakultas Teknik, Jurusan Teknologi Industri Universitas Negeri Malang. 
Lies Suprapti. 2005. Selai dan Cake. Soekarto,T.Soewarno. 1985. Penilaian Yogyakarta. Penerbit: Kanisius

Sarwono. B. 2005. Ubi Jalar Cara Budi Daya yang tepat, Efisien dan Ekonomis.Jurnal Seri Agribisnis. Jakarta.Penerbit : Swadaya. Organoleptik Untuk Industri Pangan dan Hasil Pertanian. Jakarta. Penerbit: Bhatara Karya Aksara 